\title{
Triathlon-Related Overuse Injury and Medical Issues
}

\author{
Chan-Ho Park, Yi-Sub Kwak ${ }^{1}$ and Tae-Un Kim² ${ }^{2}$ \\ Research Institute of Sport Science, Pusan National University, Busan 609-735, Korea \\ ${ }^{1}$ Department of Physical Education, Dong-Eui University, Busan 614-714, Korea \\ ${ }^{2}$ Department of Physical Education, Pusan National University, Busan 609-735, Korea
}

Received October 14, 2009 / Accepted November 14, 2009

\begin{abstract}
As the nature of triathlons is competition in three successive sports, triathletes experience elevated levels of stress on the body that are absent in single-sport athletic events, and consequently there are more potential medical problems to prepare for. Triathletes can also experience problems such as hypothermia, heat illness, excessive exposure to ultraviolet radiation, musculoskeletal injuries and trauma, immunosuppression, and haemolysis. Depending on the potentiality of such above-listed problems occurring in any given race, race organizers will prepare preventative measures and treatments accordingly. Olympic distance is not the only triathlon racing distance. Sprints, which are normally around half the Olympic distance, are common distances, as well as Long ( $2 \mathrm{~km}$ swim, $80 \mathrm{~km}$ bike, $20 \mathrm{~km}$ run), Ironman (3.8 km swim, $180 \mathrm{~km}$ bike, $42 \mathrm{~km}$ run), and ultra-distance events varying in length. Races of longer duration normally result in a higher percentage of athletes experiencing the above-mentioned medical problems, as well as inducing additional health risks such as hyponatraemia.

Minimizing the occurrences of serious health issues is possible through the following means: carefully preparing for the probable race-day weather conditions; proper management and organization of the race; preparing an extensive water-safety and ground-course safety plan; distributing necessary nutrition along the course; and stressing the importance for athletes to have proper knowledge concerning race nutrition, biomechanical technique, physical preparation, and utilization of safe equipment. While risks of competing in triathlon are many, the instances of such medical problems are not excessive, and the triathlon has a reputation of being a reasonably safe sport as long as athletes with high risk take added precautions.
\end{abstract}

Key words : Triathlon, overuse injury, hyponatraemia, immunosuppression, medical problem

\section{서 론}

1970년 중반에 시작된 트라이애슬론(Triathlon)은 수영, 사 이클, 달리기를 한 선수가 연이어 실시하는 스포츠로 다양한 경기거리로 구성되어 있다. 수영 $750 \mathrm{~m}$, 사이클 $20 \mathrm{~km}$, 달리기 $5 \mathrm{~km}$ 의 거리로 구성된 단거리(Sprint Distance: SD)와 수영 $1.5 \mathrm{~km}$, 사이클 $40 \mathrm{~km}$, 달리기 $10 \mathrm{~km}$ 의 거리로 구성된 올림픽 거리(Olympic Distance: OD) 그리고 4시간 이상 지속되는 울 트라 지구력 스포츠에 속하는 수영 $2 \mathrm{~km}$, 사이클 $80 \mathrm{~km}$, 달리 기 $20 \mathrm{~km}$ 의 거리로 구성된 장거리(Long Distance: LD)와 수영 $3.8 \mathrm{~km}$, 사이클 $180.2 \mathrm{~km}$, 달리기 $42.2 \mathrm{~km}$ 의 거리로 구성된 철인거리(Ironman Distance: ID) 등이 있다. 트라이애슬론 경 기는 올림픽과 아시안게임 정식종목으로 국제적인 경쟁이 더 욱 치열해지고 있으며, 다른 스포츠 종목과 같이 국제적인 수 준의 경기력을 유지하고, 향상시키기 위하여 선수들이 실시하 는 과도한 훈련 뿐 아니라 극한에 도전하는 스포츠로 즐기는 사람들이 증가하고 있기 때문에 훈련과 경기 중에 발생될 수

\footnotetext{
*Corresponding author

Tel : +82-51-510-1641, Fax : +82-51-515-1991

E-mail : tukim@pusan.ac.kr
}

있는 부상 발생률과 의학적 문제점도 그 만큼 증가 할 수 있다 $[3,6,8,22]$. 과사용 부상의 발생률은 엘리트 선수가 동호인에 비해 더 높게 나타나며 $[8,51]$, 선수들의 부상은 건강을 위협할 뿐 아니라 국제적인 스포츠 경쟁력 저하를 초래할 수 있으므 로 선수들의 부상을 예방하기 위한 대책이 요구되며, 이를 위 해서는 각 스포츠 종목마다 가지고 있는 특성을 고려한 부상 발생률 및 부상의 유형, 부상의 위험 요인들을 분석하는 일이 필요하다. 선수 이외의 일반 참가자들 또한 다양한 자연환경 과 경기거리에서 완주해야 하기 때문에 부상과 의학적 문제에 직면할 수 있다. 현재까지 트라이애슬론과 관련하여 보고되고 있는 의학적 위험요인들은 저체온증[19], 저나트륨혈증 (hyponatraemia) [27,41,43], 열사병[16,19], 자외선[23], 면역억 압(immunosuppression) [7,28,32,35,42], 용혈증(haemolysis) $[19,25]$ 등을 포함하고 있다. 이처럼 트라이애슬론이 짧은 역사 에도 불구하고 국제적인 스포츠로 빠르게 성장하였을 뿐 아니 라 주말 레저 스포츠 활동으로 즐기는 사람이 증가하고 있지 만, 스포츠현장에서 발생할 수 있는 부상과 의학적 위험요인 에 대한 국내에서의 연구가 부족하여 현장에서의 적용은 미흡 하며, 선수 및 동호인, 코치 그리고 대회 운영자들 모두가 숙지 할 수 있는 과학적 근거 자료의 필요성이 중요시되고 있는 
실정이다.

따라서 본 연구자는 트라이애슬론 훈련과 경기 중에 발생 될 수 있는 과사용 부상 및 의학적 위험 요인에 대한 연구문헌 들을 고찰하여 스포츠 활동에 직접 참여하는 엘리트 선수 및 동호인 그리고 스포츠 현장에서 선수들을 지도하는 코치와 대회를 주최하는 관계자들에게 트라이애슬론과 관련된 과사 용 부상과 의학적 위험요인에 대한 기초자료를 제공하여 이러 한 위험요인들을 미연에 예방하거나 감소시키는데 도움을 줄 수 있는 기초자료를 제시하고자 한다.

\section{본 론}

\section{트라이애슬론과 과사용 부상}

스포츠 의학 및 생리학자들은 트라이애슬론 훈련은 골격근 에 주어지는 스트레스를 균형 있게 분산시키는 크로스 트레이 닝(cross-training)의 효과로 인하여 과사용 부상(overuse injuries)의 발생률이 단일 스포츠 종목 보다 적을 것이라고 생각 해왔다. 그러나 엘리트 선수 및 동호인들은 단일 스포츠 종목 의 선수들 보다 주당 훈련시간이 더 많았고, 부상 발생률 또한 더 높은 것으로 보고되었다[3,6]. 과사용은 스트레스의 증가와 빼, 관절, 근육, 건 또는 신경의 손상을 일으키며, 지금까지 트라이애슬론 훈련과 경기 중에 발생될 수 있는 과사용 부상 은 목통증(neck pain) [49,50], 요통(low-back pain) [18,26,49], 근육과 건 부상, 인대부상, 만성적인 통증(chronic complaints) [6] 등이 보고되고 있다. 대부분의 과사용 부상은 달리기 훈련 시 가장 많이 발생하였으며, 그 다음으로 사이클 훈련, 그리고 수영 훈련 시 가장 적게 나타나는 것으로 보고되었다[14,21, 26]. 특히, 근육과 건 부상의 발병 원인으로는 달리기훈련이 $65.9 \%$ 로 사이클훈련의 $14.4 \%$ 와 수영훈련의 $14 \%$ 에 비해 발생 률이 높은 것으로 보고되었으며[6], 각 종목별 부상으로 인해 훈련을 중단한 경우는 수영 훈련이 $16 \%$, 사이클 훈련이 $37 \%$, 달리기 훈련이 $78 \%$ 로 가장 높게 나타났고[5], 달리기 훈련에 의하여 발생되는 과사용 부상은 무릎과 발목부상이 $50-75 \%$ 를 차지하였다[47]. ID 경기에 참가하기 위하여 훈련하는 선수들 의 경우, 대부분의 골격근 부상이 달리기 훈련에 의하여 발생 되었으며, 이 가운데 무릎부상이 $41.6 \%$, 발목부상이 $40.2 \%$, 어 깨부상이 $12.3 \%$ 의 비율로 보고되어[6], 트라이애슬론 종목 가 운데 달리기 훈련으로 인하여 부상의 발생률이 높은 것을 알 수 있다. 이러한 달리기 부상은 과훈련(overtraining), 부적절 한 달리기 동작, 달리는 장소의 표면, 부적절한 스트레칭에 의하여 발생된다. 경기거리에 따른 부상 발생률은 ID 경기에 출전하는 선수들은 $91 \%$ 의 부상경험을 보고하였고[26], SD와 $\mathrm{OD}$ 경기에 출전하는 선수들은 $49-75 \%$ 의 부상경험을 보고하 였다[4,22]. 이처럼 트라이애슬론 경기거리가 길어짐에 따라 부상의 발생률 또한 증가하며, 이러한 과사용 부상은 비시즌 기 보다 시합 시즌기에 더 많이 발생하였고[3], 경기 중에
$18.7 \%$ 의 발생률 보다 훈련 중에 $81.3 \%$ 의 발생률로 더 높게 나타났다[6]. 이러한 결과는 경기 보다 훈련에 소요되는 시간 이 더 많았기 때문이며, 운동경력[3,14], 훈련거리[4,14], 훈련 시간[4,14,26], 훈련빈도[14], 훈련강도[14,26], 대회참가횟수 [14], 과거 부상의 병력[3], 부적절한 준비운동과 정리운동[3]이 부상 발생률과 관련이 있는 것으로 보고되었다. 따라서 부상 예방을 위해서 이러한 요소들을 감안하여 체계적이고 과학적 인 훈련 프로그램 구성이 중요시되며, 준비운동과 정리운동을 실천하는 행동습관변화는 부상의 발병 위험률을 감소시킬 수 있으므로 훈련 전과 후에 실천하는 일이 무엇보다 중요한 것 으로 사료된다.

사이클 선수들에게 가장 일반적으로 나타나는 통증은 주로 목과 허리부분에서 자주 발생되며, 이와 같은 통증은 일반적 으로 근육과 인대에 손상을 유발시켜 경추(cervical spine)의 기능을 더욱 악화 시킨다. 사이클 선수의 경추부상은 허리부 상 보다 더 일반적으로 나타나는 과사용 부상이다[2]. 그러나 트라이애슬론 선수의 경추부상은 허리부상 보다 발생 빈도가 낮은 것으로 보고되었다[14]. ID의 경기에서 사이클 훈련거리 는 경기력을 예측할 수 있는 중요한 요인[10]이며, 사이클 훈련 거리의 증가는 요통 부상(lower back injury)과 관련 있는 것으 로 보고되었다[18]. 이러한 원인은 훈련 중에 에어로바 (aerobar)를 이용하여 유체역학적인 자세(aerodynamic body position)를 장시간 유지 할 경우에 발생될 수 있다[10]. 역학적 연구에서 트라이애슬론 선수들에게 나타나는 통증으로 요통 이 $67.8 \%$, 목통증이 $48.3 \%$ 의 비율로 각각 나타났으며 [49], 이 러한 통증들은 과사용 부상으로 발전하여 척추 부상에 영향을 미칠 수 있는 위험요인이 될 수 있다. 요통은 상기도 감염 다음 으로 발생 빈도가 높은 질환으로서 선수 뿐 아니라 많은 사람 들이 요통으로 인하여 자신의 직업 및 일상생활 활동에 지장 을 받고 있다. 따라서 $\mathrm{ID}$ 경기에 참가하는 선수 및 동호인들은 요통 부상 예방을 위하여 사이클 훈련거리와 빈도를 점진적으 로 증가시키는 것이 필요하며, 요통의 원인이 체간의 근력과 근지구력의 약화, 복부 근력과 등 근력의 불균형에 의하여 발 생되기 때문에, 이러한 원인을 예방하기 위해서는 체간의 근 력과 근지구력을 강화시키는 훈련과 중심 안정화(core stabilization) 훈련이 요구된다. 그리고 사이클 장비를 자신의 몸에 정확하게 맞추어 사용하는 것이 이러한 부상을 예방하는데 중요하며, 장시간 에어로바의 사용 시간을 줄이는 것이 필요 하다.

엘리트 선수의 비시즌기 주당 평균 훈련거리와 훈련시간은 동호인 보다 많으며, 시즌기에는 이보다 더 많은 훈련량을 소 화해내야 한다. 이러한 결과로 과사용 부상의 발생률이 엘리 트 선수가 동호인에 비해 더 높게 나타난다[14,51]. Shaw 등 [34]은 훈련시간과 부상 발병률 사이의 관계를 U자 형태 (U-shape)라고 보고하였다. 즉, 훈련시간이 아주 적거나 또는 아주 많은 선수들이 부상 발생률이 높다는 이론이며, 주당 훈 
련시간이 8-10시간일 경우 부상 발생률이 가장 적었다고 보고 하였다. 부상으로 인한 훈련중단은 엘리트 선수와 동호인의 삶의 질에 영향을 미칠 수 있으며[50], 부상으로 인하여 선수 생명이 단축되는 경우를 종종 볼 수 있다. 따라서 과사용 부상 은 엘리트 선수 및 동호인의 훈련과 경기력 그리고 건강에 부정적인 영향을 미칠 수 있기 때문에 예방과 적절한 치료가 중요시된다. 트라이애슬론 관련 과사용 부상들은 각 단일종목 의 스포츠에서 나타나는 부상들과 유사한 형태를 보이고 있으 나, 각 종목에 대한 훈련 습관이 부상의 유형에 영향을 미칠 수 있음을 인식해야 하며 특히, 수영과 사이클을 마치고 체력 이 감소된 상태에서 달리기를 시작 할 경우 부상의 발생률이 단일 스포츠 종목 보다 증가할 수 있다.

\section{트라이애슬론과 의학적 위험요인}

트라이애슬론 경기에서 제일 먼저 시작되는 수영경기는 바 다, 강, 호수 등 다양한 자연환경에서 실시된다. 따라서 수온은 수영 경기 중에 선수들의 안전과 직접적으로 관련이 있는 가 장 중요한 요인이다. 수영경기 중에 열 손실이 육상에서 운동 할 때 보다 더 많이 발생한다[20]. 이러한 결과로 수온이 적절 한 범위를 벗어날 경우 저체온증(hypothermia)과 고체온증 (hyperthermia)의 발병률은 증가하게 된다. 수영시 열 손실 비 율은 신체조성과 관련이 있으며[20], 엘리트 선수의 체지방률 은 매우 낮은 것으로 보고되었다[37]. 따라서 엘리트 선수는 상대적으로 차가운 수온에 저항력이 약 할 수 있다는 사실을 추측할 수 있다. 낮은 수온으로 발생되는 체온의 감소는 일반 적으로 사용하고 있는 보온복(wetsuit)을 착용함으로써 대부 분 예방 할 수 있다[44]. 그러나 엘리트 선수의 경우, 보온복 착용이 부력을 증가시켜 경기력에 영향을 미칠 수 있기 때문 에, 국제트라이애슬론연맹(ITU)은 보온복 착용기준을 수온이 $20^{\circ} \mathrm{C}$ 이상에서는 엄격하게 제한하고 있다. 그러나 수영에 적절 한 수온이 $25.5-28^{\circ} \mathrm{C}$ 이며, $25.5^{\circ} \mathrm{C}$ 이하에서 일부 선수들은 체온 이 유의하게 감소 될 수 있다는 가능성을 제시[44]하고 있기 때문에 엘리트 선수들도 $25.5^{\circ} \mathrm{C}$ 까지 보온복 사용을 허용하는 것이 고려되어야 할 것이다. 또한 수온이 $5-15^{\circ} \mathrm{C}$ 로 매우 낮은 상태에서 수영을 마쳤을 경우, 사이클 경기구간 초반에는 저 체온증이 발생될 수 있다[44]. 추운 날씨와 우천 상황에서 사이 클 경기를 실시할 경우에는 저체온증에 의한 사고의 위험을 증가시킬 수 있다. 왜냐하면 저체온증은 선수들의 집중력과 운동제어능력을 일시적으로 감소시키기 때문이다. 따라서 우 천과 추운 날씨와 같은 환경 상황에서 경기가 진행될 경우에 는 선수들의 저체온증에 대한 주의를 기울여야 한다. 그러나 적절한 수온의 범위를 넘어선 수온의 유의한 증가는 수영 경 기 중에 중심체온(core body temperature)을 증가시키는 결과 를 초래한다[13]. 중심체온의 증가는 사이클 경기 중 열손실을 통하여 비교적 빠르게 감소 될 수 있지만, 보온복의 착용은 수영 경기 중에 중심체온의 증가에 영향을 미친다[13]. 그리고
수영 경기에서 수분섭취의 제한은 탈수의 가능성을 증가시키 며, 탈수는 중심체온 상승과 심박수를 증가시켜 혈압과 심박 출량(stroke volume)을 감소시킨다[17,31]. 엘리트 선수에게는 수온에 따른 경기규칙이 적용되지만 동호인의 경우 경기규칙 이 적용되지 않는다. 따라서 수온이 지나치게 높은 경우에 동 호인들의 보온복 착용은 고체온증을 유발 시킬 수 있음을 인 식해야 할 것이다.

스포츠음료는 운동으로 인해 체내에서 빠져나간 수분과 전 해질을 보충해 주어 피로회복을 돕는 기능성 음료를 말하며, 주요 성분으로는 당질(탄수화물)을 비롯해 나트륨, 칼륨, 마그 네슘 등의 무기질을 함유하고 있으며, 비타민 C가 포함되기도 한다[33]. 트라이애슬론 경기 특성상 수영과 사이클 경기 후의 피로는 연이어 실시되는 달리기 경기력에 영향을 미치게 된 다. 그러나 수영 경기 중에는 수분 및 에너지 보충이 어렵기 때문에 사이클 경기 중에 피로해진 신체를 빨리 회복시키는 일은 선수들의 경기력 향상을 위해 중요하다. 특히 땀으로 손 실되는 체수분의 보충과 정상적인 혈청 삼투압 유지 및 혈장 량과 혈당 유지 그리고 최적의 경기력 유지 등이 재충전의 중요한 전략이다. 수분섭취 계획을 적절하게 사용하여 수분을 보충시키는 일과 탄수화물을 포함하고 있는 음료 섭취는 혈당 을 유지하는데 중요하며 특히, 90 분 이상 지속되는 운동에서 는 더욱 중요하다[17]. 수분, 전해질 그리고 당의 재보충과 혈 장량의 유지는 트라이애슬론 경기력 향상 뿐 아니라 피로회복 과 체력증진에 중요하기 때문에 사이클 경기 중에는 선수들이 재충전을 할 수 있도록 음료보급소(fluid station) 설치가 요구 된다. $\mathrm{OD}$ 경기에서는 적어도 사이클 경기구간 중간지점에 음 료보급소가 설치되어야하며, $\mathrm{LD}$ 경기와 ID 경기에서 적절한 거리마다 음료보급소가 설치되어야 한다. 그리고 제공되는 음 료수에는 탄수화물이 포함되는 것이 권장된다.

트라이애슬론의 달리기 경기구간에서 선수들에게 나타날 수 있는 몇 가지 의학적 위험요인들은 대기온도(ambient temperature), 상대습도(relative humidity), 경기 중 과도한 음료 섭취, 자외선 노출과 관련 있다. $\mathrm{SD}$ 와 $\mathrm{OD}$ 경기에 참가하는 엘리트 선수들은 달리기 경기구간에서 열사병(heat stroke)에 노출될 수 있다[19]. 왜냐하면 선수들의 대부분은 탈수와 피로 한 상태 그리고 가장 더운 날씨 상황 속에서 달리기 경기를 시작한다. 이렇게 시작되는 시점에서 선수들의 체온은 일반적 인 달리기 경기 상황에 비해 증가될 수 있고, 혈장량은 감소 될 수 있으며, 산소소비(oxygen costs)와 심박수는 증가한다 [15]. 특히, 엘리트 선수는 최대산소섭취량의 $90 \%$ 또는 그 이 상의 강도에서 달리기 경기구간을 완주해야 하며[19], 치열한 경쟁 속에서 일반적으로 많은 수분을 섭취할 수 없기 때문에 이러한 위험에 더 쉽게 노출될 수 있다[17]. 따라서 대기온도와 습도가 높을 경우 엘리트 선수들은 열사병의 발병 위험성에 노출될 수 있음을 고려해야한다. ACSM에 따르면, 열사병을 악화시키는 요인들로 비만(obesity), 허약체력(poor fitness), 
탈수(dehydration), 열사병의 병력(history of heat stroke), 수 면결핍(sleep deprivation), 땀샘기능장애(sweat-gland dysfunction), 그리고 시합 1주전 질병(illness 1-week prior) 상태 등이라고 하였다[1]. 따라서 일반 동호인의 경우에도 무더운 날씨 상황에서 경기에 참가할 경우 열사병을 악화시킬 수 있 는 요인들을 잘 인식해야 할 것이다.

운동 유발성 저나트륨혈증(Exercise-associated hyponatremia; EAH)은 마라톤 $(42.2 \mathrm{~km})$, 트라이애슬론 $(226 \mathrm{~km})$ 그리 고 울트라마라톤 $(100 \mathrm{~km})$ 경기에 참가하는 선수들에게 발병 되고 있으며[41], 발작(seizures), 혼수상태(coma), 사망을 초래 할 수 있다[19]. LD와 ID 경기 중에도 저나트륨혈증이 보고되 었다[11,19,39]. 이러한 현상은 혈청 나트륨농도 감소, 발한의 감소, 과도한 수분섭취로 인한 체중증가에 의하여 발생할 수 있으며, 이러한 저나트륨혈증은 계획성 있는 수분섭취의 부재 와 장시간 경기를 수행하는 선수에게 나타날 수 있다. $\mathrm{LD}$ 와 $\mathrm{ID}$ 참가자들이 달리기 구간에서 경험할 수 있는 의학적인 위 험요인은 탈수에 비해 저나트륨혈증이 더 위험한 요인이 될 수 있다[11,40]. 대부분의 ID 참가자들은 마라톤 달리기 속도 가 느리고, 음료보급소 마다 멈춰서 과도한 양의 수분을 섭취 하게 된다[19,40]. 이러한 현상은 결국 혈청 나트륨 농도를 더 감소시키는 결과를 초래하게 된다. 따라서 ID 경기의 달리기 코스를 설계할 때, 음료보급소는 열 스트레스의 위험을 최소 화시킬 수 있도록 적절하게 설치하고, 과도하게 많은 음료보 급소 설치는 오히려 저나트륨혈증의 위험성을 증가시킬 수 있다. 또한 ID 경기 중에 발생 할 수 있는 의학적 문제들의 약 $85 \%$ 가 달리기 구간과 골인지점에서 나타나며[19], 가장 빈 번하게 발생하는 증상은 탈진(exhaustion)과 탈수이며, 그 다 음으로 나타나는 문제점들은 저나트륨혈증, 열부상(heat injury), 저혈압, 화상과 물집(blister), 근육경련(muscle cramp$\mathrm{ing}$ ) 등이다. $\mathrm{SD}$ 와 $\mathrm{OD}$ 경기 중에는 달리기 속도가 빠르고 더 높은 강도에서 경기가 진행되기 때문에 열사병의 발병 위험이 더 높고, 경기 시간이 짧은 관계로 저나트륨혈증은 발병하지 않는 것으로 보고되었다[9,27].

용혈증(hemolysis)은 근육의 기계적 충격으로 인해 발생되 고 장시간 주행 시 근욕세포의 파열을 초래하여 근육색소가 유출된다. 또한 운동선수의 과도한 훈련은 체내의 철 상태에 영향을 미치는데, 이것은 체내 철 농도 저하와 더불어 무기질 대사에 이상을 초래하여 혈중 전해질 농도의 변화를 유발시키 고 근세포막 투과성을 증가시켜서 근 피로를 유발시키는 요인 으로 작용한다[45]. 트라이애슬론 경기거리와 용혈 수치 사이 의 관련성을 연구한 결과에서 용혈증은 $\mathrm{OD}$ 경기 보다 $\mathrm{ID}$ 경기 에 참가한 선수들에게서 더 높게 나타나 경기거리와 관련이 있는 것으로 나타났으며[25], 지구력운동에 참가하는 선수들 이 철분 섭취가 불충분한 상태에서 장시간 동안 운동을 할 경우 철분 불균형에 걸리기 쉬우며, 철 결핍은 유산소능력과 미토콘드리아 내 철분의존효소(iron-dependent enzymes)를
감소시켜 잠재성 철 결핍 빈혈을 유발시키기도 한다[52]. 따라 서 트라이애슬론과 같이 종목 특성상 빈혈유발 가능성이 있는 선수들에게 철분보충제 병행과 빈혈 예방책이 모색되어야 할 것으로 사료된다.

인간의 면역계는 여러 가지 외적 자극에 변하고, 운동은 이 러한 중요한 외적 자극들 중의 하나이다. 적절한 운동은 건강 증진과 면역기능 향상으로 각종 질병의 예방과 치료에 효과적 이지만, 과도한 운동은 회복기간에 면역억압 현상을 유발시켜 운동 선수들의 감염 발병률을 증가시킨다[29]. 이와 관련하여 과도한 운동이 면역기능 저하 및 상기도 감염(upper respiratory track infection; URTI) 그리고 질병을 유발할 수 있다는 신경내분비 이론[38], J 곡선 이론[24]과 open window 이론 [30]이 제시된 바 있다. 이와 관련하여 트라이애슬론 훈련과 경기의 스트레스가 엘리트 선수 및 동호인의 면역기능을 억압 시킬 수 있다는 연구가 보고되고 있다[7,28,32,35,42]. 일반적으 로 급격한 운동을 하게 되면 호흡이 빨라져 호흡량이 많아지 는 한편, 많은 양의 공기를 입으로 들이마시게 되므로 자연적 으로 호흡기 점막이 건조해지게 된다. 과호흡으로 인한 타액 의 IgA 감소가 상기도 감염의 주된 원인이 될 수 있고, 초기면 역 반응에 중요한 역할을 수행하는 자연살 세포의 수가 감소 하여 감염이 되기 쉽다. 상기도 감염 증상이 선수들의 건강에 심각한 위협은 되지 않을 지라도 최상의 상태에서 경기력을 발휘해야 하는 선수들에게는 가벼운 증상이라도 승패에 영향 을 미칠 수 있으며, 훈련을 중단하거나 양질의 훈련을 실시할 수 없도록 만든다. 따라서 과도한 훈련과 경기 후에 잠재적으 로 나타날 수 있는 면역력 감소로 인한 감염질환에 특히 주의 를 기울여야 한다.

\section{결 론}

트라이애슬론 경기에 참가하는 엘리트 선수 및 동호인들이 훈련과 경기 중에 발생될 수 있는 과사용 부상과 의학적인 위험요인에 관한 본 연구는 대회를 주최하는 관계자와 선수 및 코치들에게 과사용 부상과 건강을 위협하는 위험요인에 대한 인식과 예방책을 제시하기 위함이었다. 과사용 부상은 훈련의 습관에서 비롯될 수 있으며, 국제적인 스포츠 경쟁력 저하 및 선수 생명의 단축 그리고 건강에 부정적인 영향을 미치기 때문에 이를 예방하기 위해서는 잘 못된 훈련습관을 보다 체계적이고 과학적으로 계획하는 것이 필요하다. 수영 경기구간에서 나타날 수 있는 저체온증 예방을 위해 기후조건 과 기온 등 환경적인 조건들을 고려하여 수영코스를 설계해야 하며, 경기 중에 보온복 착용을 적극 권장해야 한다. 사이클과 달리기 경기 구간에서 나타나는 의학적 문제점들은 탈수, 충 돌사고, 열사병 그리고 저나트륨혈증 등이 있으며, 위험요인 을 감소시키기 위해서는 선수들을 지속적으로 관찰하고 적절 한 음료 보충, 효율적인 경기코스 설계가 적절하게 이루어져 
야 한다. 또한 참가자들도 적절한 음료보충의 중요성과 훈련 에 의한 신체적응 능력을 향상시켜야 한다. 대회 주최 관계자 들은 트라이애슬론 경기에서 발생할 수 있는 다양한 상황에 처치 할 수 있는 준비와 이러한 상황에 대해 잘 숙지하고 있어 야 한다. 특히, 강조되는 의학적 문제점들은 $\mathrm{LD}$ 와 ID 경기에 서 나타나는 탈수와 탈진현상, 저나트륨혈증 뿐 아니라 $\mathrm{SD}$ 와 $\mathrm{OD}$ 경기에서 나타나는 열사병과 추운 날씨 속에서 경기가 진행될 경우에 나타나는 저체온증에 대처 할 수 있어야 한다. 그리고 선수와 코치들은 과도한 훈련과 경기 후에 잠재적으로 나타날 수 있는 면역력 감소로 인한 감염질환에 특히, 주의를 기울여야 하며, 감염증상이 있는 사람과 접촉 제한 등이 감염 예방을 위해 고려되어야 한다. 이상과 같이 트라이애슬론 훈 련과 경기 중에 생리적인 스트레스가 비교적 높고, 의학적 위 험요소가 많음에도 불구하고 적절한 예방 대책을 잘 활용한다 면 트라이애슬론에 참가하는 일은 안전하며, 위험요인도 감소 시킬 수 있다고 사료된다.

\section{References}

1. American College of Sports Medicine Position Stand. 1998. Exercise and physical activity for older adults. Med. Sci. Sports Exerc. 30, 992-1008.

2. Asplund, C., C. Webb, and T. Barkdull. 2005. Neck and back pain in bicycling. Curr. Sports Med. Rep. 4, 271-274.

3. Burns, J., A. M. Keenan, and A. C. Redmond. 2003. Factors associated with triathlon-related overuse injuries. J. Orthop. Sports Phys. Ther. 33, 177-184.

4. Collins, K., M. Wagner, K. Peterson, and M. Storey. 1989. Overuse injuries in triathletes. A study of the 1986 Seafair Triathlon. Am. J. Sports Med. 17, 675-680.

5. Dallam, G. M., S. Jonas, and T. K. Miller. 2005. Medical considerations in triathlon competition. Sports Med. 35, 143-161.

6. Egermann, M., D. Brocai, C. A. Lill, and H. Schmitt. 2003. Analysis of injuries in long-distance triathletes. Int. J. Sports Med. 24, 271-276.

7. Gleeson, M., W. A. McDonald, D. B. Pyne, A. W. Cripps, J. L. Francis, P. A. Fricker, and R. L. Clancy. 1999. Salivary IgA levels and infection risk in elite swimmers. Med. Sci. Sports Exerc. 31, 67-73.

8. Gosling, C. M., B. J. Gabbe, and A. B. Forbes. 2008. Triathlon related musculoskeletal injuries: the status of injury prevention knowledge. J. Sci. Med. Sport 11, 396-406.

9. Gosling, C. M., B. J. Gabbe, J. McGivern, and A. B. Forbes. 2008. The incidence of heat casualties in sprint triathlon. J. Sci. Med. Sport 11, 52-57.

10. Gulbin, J. P. and P. T. Gaffney. 1999. Ultraendurance triathlon participation: typical race preparation of lower level triathletes. J. Sports Med. Phys. Fitness 39, 12-15.

11. Hiller, W., M. O'Toole, and E. E. Fortess. 1987. Medical and physiological considerations in triathlons. Am. J. Sports. Med. 15, 164-167.

12. Inoue, Y., M. Nakao, T. Araki, and H. Ueda. 1992.
Thermoregulatory responses of young and older men to cold exposure. Eur. J. Appl. Physiol. Occup. Physiol. 65, 492498.

13. Kerr, C. G., T. A. Trappe, R. D. Starling, and S. W. Trappe. 1998. Hyperthermia during Olympic triathlon: influence of body heat storage during the swimming stage. Med. Sci. Sports Exerc. 30, 99-104.

14. Korkia, P., D. Tunstall-Pedoe, and N. Mafulli. 1994. An epidemiological investigation of training and injury patterns in British triathletes. Br. J. Sports Med. 28, 191-196.

15. Kreider, R. B., T. Boone, W. R. Thompson, S. Burkes, and C. W. Cortes. 1988. Cardiovascular and thermal responses of triathlon performance. Med. Sci. Sports Exerc. 20, 385-390.

16. Laird, R. H. 1989. Medical care at ultraendurance triathlons. Med. Sci. Sports Exerc. 1989 21, S222-225.

17. Latzka, W. A. and S. J. Montain. 1999. Water and electrolyte requirements for exercise. Clin. Sports Med. 18, 513-524.

18. Manninen, J. S. and M. Kallinen. 1996. Low back pain and other overuse injuries in a group of Japanese triathletes. Br. J. Sports Med. 30, 134-139.

19. Mayers, L. B. and T. Noakes. 2000. A guide to treating Ironman triathletes at the finishing line. Phys. Sports Med. 28, 35-50.

20. McMurray, R. G. and S. M. Horvath. 1979. Thermoregulation in swimmers and runners. J. Appl. Physiol. 46, 1086-1092.

21. Migliorini, S. 1991. An epidemiological study of overuse injuries in Italian national triathletes in the period. 1987-1990. J. Sports Traumatol. Rel. Res. 13, 197-206.

22. Migiliorini, S. 2000. The triathlon: acute and overuse injuries. J. Sports Traumatol Relat. Res. 22, 186-195.

23. Moehrle, M. 2001. Ultraviolet exposure in Ironman triathlon. Med. Sci. Sports Exerc. 33. 1385-1386.

24. Nieman, D. C. 1994. Exercise, infection, and immunity. International Journal of Sports Medicine 15, S131-S141.

25. O'Toole, M. L., W. D. Hiller, M. S. Roalstad, and P. S. Douglas. 1988. Hemolysis during triathlon races: its relation to race distance. Med. Sci. Sports Exerc. 20, 272-275.

26. O'Toole, M. L., W. D. Hiller, R. A. Smith, and T. D. Sisk. 1989. Overuse injuries in ultraendurance triathletes. Am. J. Sports Med. 17, 514-518.

27. Park, C. H. and T. U. Kim. 2009. The effect of different triathlon on weight, sodium and hematological changes. Journal of Life Science 19, 46-51.

28. Park, C. H., T. G. Park, T. U. Kim, and Y. S Kwak. 2008. Changes of immunlogical markers in elite and amateur triathletes. International Sport Med. Journal 9, 116-130.

29. Pedersen, B. K. and L. Hoffman-Goetz. 2000. Exercise and the immune system: regulation, integration, and adaptation. Physiological Reviews 80, 1055-1081.

30. Pedersen, B. K. and H. Ullum. 1994. NK cell response to physical activity: possible mechanisms of action. Medicine and Science in Sports and Exercise 26, 140-146.

31. Rehrer, N. J. 2001. Fluid and electrolyte balance in ultra-endurance sport. Sports Med. 31, 701-715.

32. Rohde, T., D. A. MacLean, A. Hartkopp, and B. K. Pedersen. 
1996. The immune system and serum glutamine during a triathlon. Eur. J. Appl. Physiol. Occup. Physiol. 74, 428-434.

33. Saiful Bachri, M., M. H. Woo, H. W. Lee, J. W. Choi, and H. S. Kim. 2009. Effects of herbal sports drinks with Omija, Maesil and Molasses on the endurance and energy metabolites of experimental animals. Journal of Life Science 19, 219-227.

34. Shaw, T., P. Howat, M. Trainor, and B. Maycock. 2004. Training patterns and sports injuries in triathletes. J. Sci. Med. Sport 7, 446-450.

35. Shinkai, S, Y. Kurokawa, S. Hino, M. Hirose, J. Torii, S. Watanabe, S. Shiraishi, K. Oka, and T. Watanabe. 1993. Triathlon competition induced a transient immunosuppressive change in the peripheral blood of athletes. J. Sports Med. Phys. Fitness 33, 70-78.

36. Simpson, G, D. Roomes, and M. D. Humphrey. 2001. Anaphylactoid reactions associated with menstruation affecting two sisters. Med. J. Aust. 175, 415-417.

37. Sleivert, G. G. and D. S. Rowlands. 1996. Physical and physiological factors associated with success in the triathlon. Sports Med. 22, 8-18.

38. Smith, J. W. and M. J. Weidermann. 1990. The exercise and immunity paradox: A neuroendocrine/cytokine hypothesis. Medical Science Research 18, 749-753.

39. Speedy, D. B., J. G. Faris, M. Hamlin, P. G. Gallagher, and R. G. Campbell. 1997. Hyponatremia and weight changes in an ultradistance triathlon. Clinical Journal of Sport Medicine 7, 180-184.

40. Speedy, D. B., T. D. Noakes, I. R. Rogers, I. Hellemans, N. E. Kimber, D. R. Boswell, R. Campbell, and J. A. Kuttner. 2000. A prospective study of exercise-associated hyponatremia in two ultradistance triathletes. Clinical Journal of Sport Medicine 10, 136-141.

41. Speedy, D. B., I .R. Rogers, T. D. Noakes, S. Wright, J. M. D. Thompson, R. Campbell, I. Hellemans, N. E. Kimber, D. R. Boswell, J. A. Kuttner, and S. Safih. 2000. Exercise-induce hyponatremia in ultradistance triahletes is caused by inappropriate fluid retention. Clinical Journal of Sport Medicine
10, 272-278.

42. Steerenberg, P. A., I. A. van Asperen, A. van Nieuw Amerongen, A. Biewenga, D. Mol, and G. J. Medema.. 1997. Salivary levels of immunoglobulin A in triathletes. Eur. J. Oral. Sci. 105, 305-309.

43. Sulzer, N. U., M. P. Schwellnus, and T. D. Noakes. 2005. Serum electrolytes in Ironman triathletes with exerciseassociated muscle cramping. Med. Sci. Sports Exerc. 37, 1081-1085.

44. Trappe, T. A., R. D. Starling, A. C. Jozsi, B. H. Goodpaster, S. W. Trappe, T. Nomura, S. Obara, and D. L. Costill. 1995. Thermal responses to swimming in three water temperatures: influence of a wet suit. Med. Sci. Sports Exerc. 27, 1014-1021.

45. van Beaumont, W., S. Underkofler, and S. van Beaumont. 1981. Erythrocyte volume, plasma volume, and acid-base changes in exercise and heat dehydration. J. Appl. Physiol. 50, 1255-1262.

46. van Mechelen, W. 1992. Running injuries. A review of the epidemiological literature. Sports Med. 14, 320-335.

47. van Mechelen, W., H. Hlobil, and H. C. Kemper. 1992. Incidence, severity, aetiology and prevention of sports injuries. A review of concepts. Sports Med. 14, 82-99.

48. van Mechelen, W., H. Hlobil, H. C. Kemper, W. J. Voorn, and H. R. de Jongh. 1993. Prevention of running injuries by warm-up, cool-down, and stretching exercises. Am. J. Sports Med. 21, 711-719.

49. Villavicencio, A. T., S. Burneikiene, T. D. Hernández, and J. Thramann. 2006. Back and neck pain in triathletes. Neurosurg. Focus 21, E7.

50. Villavicencio, A. T., T. D. Hernández, S. Burneikiene, and J. Thramann. 2007. Neck pain in multisport athletes. J. Neurosurg. Spine 7, 408-413.

51. Vleck, V. E. and G. Garbutt. 1998. Injury and training characteristics of male Elite, Development Squad, and Club triathletes. Int. J. Sports Med. 19, 38-42.

52. Weight, L. M., M. J. Byrne, and P. Jacobs. 1991. Haemolytic effects of exercise. Clin. Sci. 81, 147-152. 


\section{초록 : 트라이애슬론의 과사용 부상과 의학적 위험요인에 대한 고찰}

박찬호 · 곽이섭 ${ }^{1} \cdot$ 김태운 $^{2}{ }^{*}$

(부산대학교 체육과학연구소, ${ }^{1}$ 동의대학교 체육학과, ${ }^{2}$ 부산대학교 체육교육과)

트라이애슬론은 수영, 사이클, 달리기로 구성된 스포츠로 단일종목의 스포츠에 참가할 때 보다 잠재적인 의학적 위험요인을 더 많이 포함하고 있다. 과사용은 스트레스의 증가와 빼, 관절, 근육, 건 또는 신경의 손상을 일으키며, 지금까지 트라이애슬론 훈련과 경기 중에 발생될 수 있는 과사용 부상은 목통증, 요통, 근육과 건 부상, 인대부상, 만성적인 통증 등이며, 대부분의 과사용 부상은 달리기 훈련시 가장 많이 발생된다. 또한 트라이애슬론 참가자들은 다양한 자연환경과 경기거리에서 완주해야 하는 만큼 부상 이외의 의학적 문제에 직면할 수 있으며, 현재까지 트라이애슬론과 관련하여 보고되고 있는 의학적 위험요인들은 저체온증, 저나트륨혈증, 일사병, 자외선에 과도한 노출, 면역억압, 심리적인 탈진현상, 용혈증 등을 포함하고 있다. ID 경기 중에 발생 할 수 있는 의학적 문제들 가운데 가장 빈번하게 발생하는 증상은 탈진과 탈수현상이며, 그 다음으로 나타나는 문제점들은 저나트륨혈증, 열부상, 저혈압, 화상과 물집, 근육경련 등이다. 그러나 $\mathrm{SD}$ 와 $\mathrm{OD}$ 경기 중에는 달리기 속도가 빠르고 더 높은 강도에 서 경기가 진행되기 때문에 일사병의 발생 위험이 더 높고, 경기 시간이 짧은 관계로 저나트륨혈증은 발생하지 않는다. 본 연구는 트라이애슬론 훈련과 경기 중에 발생 될 수 있는 과사용 부상과 의학적 위험 요인에 대한 연구문 헌들을 고찰하여 스포츠 활동에 직접 참여하는 엘리트 선수 및 동호인 그리고 스포츠 현장에서 선수들을 지도하는 코치와 대회를 주최하는 관계자들에게 트라이애슬론과 관련된 과사용 부상과 의학적 위험요인에 대한 기초자료를 제공하여 이러한 위험요인들을 미연에 예방하거나 감소시키는데 도움을 줄 수 있는 기초자료를 제시하고자 한다. 